\title{
Postawy młodzieży akademickiej wobec transplantacji a ich poczucie koherencji
}

\begin{abstract}
Streszczenie
W artykule przedstawiono związki postaw badanych wobec transplantacji z ich poczuciem koherencji. Wyniki uzyskano po analizie danych statystycznych zebranych w grupie 467 studentów. W badaniu wykorzystano autorski kwestionariusz i skalę do badania postaw młodzieży akademickiej wobec transplantacji oraz Kwestionariusz Orientacji Życiowej (SOC-29) Antonovsky’ego. Uzyskane wyniki dowodzą, że nie istnieje zależność, która uprawniałaby do stwierdzenia, że poczucie koherencji badanych ma istotny statystycznie związek z ich postawą wobec transplantacji. Poczucie koherencji koreluje dodatnio z jednym z komponentów tworzących postawę wobec transplantacji (poziom wiedzy). Oznacza to, iż osoby z wysokim poczuciem koherencji istotnie częściej posiadają wyższy poziom wiedzy odnoszącej się do transplantacji. Dane potwierdziły istnienie zależności pomiędzy poziomem wiedzy badanych związanej z zagadnieniem transplantacji a wszystkimi komponentami tworzącymi poczucie koherencji, czyli poczucie zaradności, poczucie sensowności i poczucie zrozumiałości. Istnieje konieczność podjęcia współczesnego wyzwania pedagogicznego, jakim jest edukacja zdrowotna, której celem będzie kształtowanie postaw społecznych wobec transplantacji. Należy również wzbogacić program edukacyjny w działania kreujące wysokie poczucie koherencji u ich adresatów, co z założenia powinno mieć prozdrowotne konsekwencje dla szerokiego grona beneficjentów.
\end{abstract}

1 Marta Mirosława Perkowska, Wydział Nauk o Edukacji, Uniwersytet w Białymstoku, Polska, e-mail: marta.perkowska@uwb.edu.pl, ORCID ID: https:///orcid.org/0000-0002-2856-9800. 


\title{
Słowa kluczowe:
}

edukacja zdrowotna, transplantacje, postawa, koherencja, młodzież akademicka

\begin{abstract}
The article explores the relationship between the attitudes of the respondents towards transplantation and their sense of coherence. The presented results were obtained through the statistical analysis of data collected in a group of 467 students. The study used a self-designed questionnaire and scale to study attitudes of academic youth towards transplantation alongside Antonovsky's Orientation to Life Questionnaire (SOC-29). The results obtained prove that there is no correlation that would justify the conclusion that the sense of coherence of the respondents has a statistically significant connection with their attitude towards transplantation. However, the sense of coherence positively correlates with one of the components of the attitude towards transplantation. This concerns the level of Knowledge, which means that people with a high sense of coherence are significantly more likely to have a higher level of Knowledge related to transplantation. The data confirmed the existence of a correlation between the level of knowledge of the respondents related to the issue of transplantation and all the components constituting a sense of coherence, i.e. a manageability, meaningfulness and comprehensibility. Conclusions formulated on the basis of the obtained results point to the necessity of taking up a contemporary pedagogical challenge, which is health education aimed at shaping social attitudes towards transplantation. An additional recommendation is to enrich educational programs with activities the goal of which is to create a high sense of coherence in their recipients, which, by definition, should have pro-health consequences for a wide group of beneficiaries.
\end{abstract}

\section{Keywords:}

health education, transplantation, attitude, coherence, academic youth

\section{WSTĘP}

W artykule przedstawiono zależności pomiędzy postawą, jaką przejawia młodzież akademicka względem ratowania życia i zdrowia ludzkiego za pomocą zabiegów medycyny transplantacyjnej (Perkowska, 2019) a ich poczuciem koherencji. Problem ten uważam za istotny z perspektywy pedagogiki społecznej, a w szczególności pedagogiki zdrowia, gdyż opierając się na rozważaniach Syrek (2008), sądzę, że transplantacje wpisują się w salutogenetyczny model postrze- 
gania zdrowia. Tym samym wydaje się zasadne, aby odnieść postawy badanych wobec transplantacji do kluczowego dla tej koncepcji pojęcia, jakim jest poczucie koherencji. Można ją rozumieć jako globalną orientację życiową człowieka, umożliwiającą osiągnięcie i pozostawanie w dobrostanie, pomimo różnorodnych wpływów środowiskowych. Problematyka poczucia koherencji, korelując z pozostawaniem w zdrowiu, jest podejmowana w licznych publikacjach (zob. np.: Mattila, Rautava, Honkinen i in., 2011; Binnebesel, 2006; Dolińska-Zygmunt, 2001; Mittelmark, Sagy, Eriksson i in., 2017; Sęk, 2001). W badaniu koherencji stosunkowo nowym kierunkiem są rozważania pedagogiczne. Cudowska (2017) weryfikuje hipotezę o istnieniu relacji pomiędzy poczuciem koherencji odzwierciedlającej dobrostan psychiczny jednostki a jej twórczą orientacją życiową. Lnica-Ćwikła (2018), po przeanalizowaniu literatury dotyczącej uwarunkowań rozwoju poczucia koherencji, rekomenduje możliwość jej kształtowania opartą na założeniach pedagogiki personalistycznej. Przyjmując, że globalna orientacja życiowa ma wpływ na zdrowie, to warte uwagi jest rozważenie, czy poczucie koherencji może być w jakikolwiek sposób powiązane z postawami społecznymi wobec transplantacji.

\section{TRANSPLANTACJA JAKO METODA LECZENIA}

Transplantacja jest metodą leczenia, umożliwiającą ratowanie zdrowia i życia ludzi. Polega na zastąpieniu niewydolnych narządów, lub ich części, zdrowymi. Etymologia tego terminu wywodzi się z języka łacińskiego. Transplatare tłumaczony jest jako czynność przesadzania, szczepienia (Guzik-Makaruk, 2008). Przeprowadzane są różne rodzaje transplantacji. Przeszczepy mogą być dokonywane w obrębie jednego organizmu (autotransplantacja). Dawca i biorca mogą należeć do tego samego gatunku. Można również podejmować ksenotransplantacje (określane także jako transplantacje ksenogeniczne, ksenogenetyczne, heterogeniczne, heterologiczne i heterotransplantacje), w których biorcą jest człowiek, a dawcą zwierzę. Guzik-Makaruk (2008, s.29) zwraca uwagę na rozważania zaprezentowane przez Kaisera w latach 60. XX wieku. Autor stwierdził w nich, że do przeprowadzenia transplantacji mogą być użyte części z głęboko zamrożonego ciała ludzkiego (Kaiser, 1966). Uwzględniając aspekty natury moralnej, etycznej i prawnej tych kontrowersyjnych poglądów, Guzik Makaruk (2008) podkreśla, że cel transplantacji, jakim jest leczenie, nie wyklucza eksperymentów, więc w przyszłości te futurystyczne założenia Kaisera mogą stać się realne, a tym samym zmodyfikować obowiązujący obecnie sposób pojmowania transplantacji. 
Ta metoda leczenia wywiera wpływ na relacje międzyludzkie, stanowi problem społeczny (ze względu na wciąż niewystarczającą liczbę dawców), wymagający kształtowania świadomych postaw, przez co staje się obszarem zainteresowań również pedagogiki i wyzwaniem dla edukacji zdrowotnej w tym obszarze.

\section{POSTAWY WOBEC TRANSPLANTACJI}

W artykule z 1947 roku Shmit (1967) zaproponował strukturalną definicję postawy, obejmującą trzy elementy: afektywny (odnoszący się do uczuć), poznawczy (dotyczący myśli) oraz behawioralny (struktury, która dotyczy potencjalnych zachowań). Podobnie definiują postawę Katz i Stotland, według których: „postawa może być zdefiniowana jako tendencja lub predyspozycja jednostki do oceniania pewnego przedmiotu lub symbolu w określony sposób. Ocena polega na przyznaniu własności, które mogą być lokowane wzdłuż wymiaru „pożądany niepożądany”, „dobry - zły” (Nowak, 1973, s. 22). Taki rodzaj oceny wiąże się z włączeniem elementów poznawczych i afektywnych postawy wobec danego obiektu. Komponent behawioralny oznacza tendencje do zachowania się wobec przedmiotu niezależnie od wyrażania uczuć o nim. Specyfika pojęcia „postawa” sprawia, że przy jego zastosowaniu możliwe jest uzyskanie szerokiej perspektywy badawczej. Wpływa to na jego częste wykorzystywanie w badaniach społecznych. Woynarowska (2007, s.103) wskazuje na postawy jako podstawowe/kluczowe pojęcie wykorzystywane w edukacji zdrowotnej.

Badanie postawy studentów wobec transplantacji stworzyło szansę na poznanie przekonań, myśli, wiedzy, emocji oraz zachowań, jakie deklarują respondenci wobec tej metody ratowania życia i zdrowia ludzi (Perkowska, 2019). W kontekście podjętych badań treść komponentu poznawczego stanowi wiedza studentów na temat istoty transplantologii, rodzajów transplantacji i procedur prawnych związanych z przeszczepianiem narządów. Komponent uczuciowo-motywacyjny pozwala na stwierdzenie, czy dana postawa może być określona jako pozytywna lub negatywna wobec danego zjawiska. Badania postawy studentów wobec transplantacji polegało na diagnozie komponentu uczuciowo-motywacyjnego, który tworzą deklarowane przez respondentów motywy, przeświadczenia, oceny oraz uczucia związane z tematyką donacji narządów. Między zamiarem, deklaracją a czynem często pojawiają się rozbieżności, co w szczególnym punkcie uwagi stawia komponent behawioralny. Przykładem takiej sytuacji jest niespójność między deklaracjami ludzi co do ich zachowań wobec decyzji donacyjnych a ich postępowaniem wobec kwestii darowania narządów. Z prowadzonych badań doty- 
czących postawy wobec przeszczepiania narządów komunikat CBOS 2016 wynika, że 93\% Polaków popiera dawstwo narządów w celu ratowania życia i zdrowia. Wysoka deklaratywność, niestety, nie ma przełożenia na realne zachowania. W przedstawionych badaniach to zamiary, pragnienia, plany oraz deklarowane działania i zachowania studentów w zakresie dawstwa narządów tworzą komponent behawioralny postawy wobec transplantacji.

\section{POCZUCIE KOHERENCJI A POSTAWA WOBEC TRANSPLANTACJI}

Poczucie koherencji to koncepcja Antonovsky’ego (1987), która od ponad 30 lat inspiruje badaczy z różnych stron świata i różnych dyscyplin naukowych (socjologii, medycyny, psychologii, zwłaszcza psychologii zdrowia, a także pedagogiki). Naukowcy od wieków dążyli do rozwikłania zagadki zdrowia i choroby, zasadniczo stawiając pytania o to, dlaczego ludzie chorują. Antonovsky dokonał innowacji polegającej na odwróceniu koncentracji uwagi z choroby i jej przyczyn na zdrowie. Założył, że musi istnieć jakaś wewnętrzna siła/zasób warunkujący pozostawanie jednostki w zdrowiu. Pozytywną weryfikację tej hipotezy przyniosły badania w grupie kobiet, które doświadczyły traumy wojny (m.in. piekła obozów koncentracyjnych). Pomimo tak ekstremalnych przeżyć, bez wątpienia o negatywnym wpływie na zdrowie, część z nich deklarowała poczucie dobrostanu (poczucie dobrego zdrowia zarówno psychicznego, jak i fizycznego). Według Antonovsky'ego wewnętrzna siła badanych to ich globalna orientacja życiowa nazwana poczuciem koherencji, którą tworzą trzy komponenty: poczucie zrozumiałości (comprehensibility), poczucie zaradności (manageability) oraz poczucie sensowności (meaningfulness), (Antonovsky, 2005, s. 34). Sądzę, że podobne komponenty odpowiadają za kształtowanie postawy przychylnej transplantacji. Człowiek postrzegający swoje zdrowie jako zasób indywidualny, ale także społeczny, mający wysoki poziom poczucia koherencji, będzie zdolny do rozumienia donacji komórek, tkanek i narządów jako swojego wkładu w budowanie dobra, zdrowia innego człowieka (potencjalnie także swojego). Poczucie zrozumiałości może umożliwić tłumaczenie tego, że w chwili indywidualnej śmierci to, co nie będzie już potrzebne jednostce, może być cennym darem dla innych. Poczucie zaradności może wpływać na zdolność do podjęcia decyzji o donacji. Poczucie sensowności (co podkreśla wiele osób decydujących się na pośmiertną donację oraz osób bliskich, którzy godzą się na pobranie narządów od zmarłych członków rodziny) sprawi, że w perspektywie zgody na przekazanie komórek, tkanek, narządów „śmierć człowieka nabiera sensu”. W niniejszych badaniach przyjęłam 
hipotezę zakładającą związek pomiędzy wysokim poczuciem koherencji a przychylną postawą wobec zabiegów medycyny transplantacyjnej.

\section{METODA BADAŃ I BADANA GRUPA}

Za dominujący paradygmat przyjęłam pozytywistyczny model badań. Zdiagnozowanie postaw, jakie młodzi ludzie przejawiają wobec medycyny transplantacyjnej, wpisuje się w odkrywanie reguł i mechanizmów życia społecznego.

Celem empirycznym prezentowanego projektu było zbadanie korelacji postaw młodzieży akademickiej wobec transplantacji z poczuciem koherencji respondentów. W badaniach posłużyłam się metodą sondażu diagnostycznego oraz metodą modelowania, w celu konceptualizacji postawy studentów wobec transplantacji. Autorski kwestionariusz ankiety dla studentów, zatytułowany „Moja postawa wobec transplantacji”, pozwolił na zdobycie informacji na temat wiedzy, poglądów, opinii i przekonań respondentów dotyczących transplantacji. Wykorzystałam także autorską skalę do badania stosunku uczuciowo-motywacyjnego studentów wobec transplantacji. Materiał empiryczny pozyskany za pomocą tych narzędzi był bazą do wyliczeń statystycznych przeprowadzanych w ramach trzech komponentów tworzących model postawy. W badaniu rzetelności (alfa Cronbacha) poszczególne skale uzyskały następujące wyniki: Zachowanie $=0,91$; Wiedza $=0,78$; Uczucia $=0,80$.

Do badania poziomu poczucia koherencji użyłam narzędzia Antonovsky’ego: Kwestionariusz Orientacji Życiowej (SOC-29), w polskiej adaptacji z 1993 roku, dokonanej przez zespoły z Zakładu Psychologii Klinicznej IPN w Warszawie, Zakładu Psychoprofilaktyki Instytutu Psychologii UAM w Poznaniu oraz Zakładu Psychologii Pracy Instytutu Medycyny Pracy w Łodzi. Kwestionariusz ten ma dobre właściwości psychometryczne: $\alpha$ Cronbacha dla całej skali wynosi 0,85 iod 0,72 do 0,75 dla podskal. Stabilność retestowa skali waha się od 0,72 do 0,83 $(\mathrm{p}<0,001)$. Za jego pomocą można oszacować globalne poczucie koherencji i jego trzy komponenty: poczucie zrozumiałości, sterowalności i sensowności (Mroziak, 1996).

Dobór osób do badań był celowy. Studenci to z założenia grupa społeczna odznaczająca się wysokim poziomem zaangażowania społecznego, odpowiedzialna za kreowanie nowych idei, poglądów, postaw. Tematyka transplantacyjna wpłynęła także na wybór kierunków, na których kształci się badana młodzież, ponieważ każdy z nich jest w jakimś stopniu z nią powiązany. W badaniu uczestniczyło 467 studentów Uniwersytetu w Białymstoku, Uniwersytetu Medycznego w Białym- 
Tabela 1. Charakterystyka badanych studentów

\begin{tabular}{|c|c|}
\hline Zmienne niezależne & Wartości zmiennych \\
\hline Płeć & $\begin{array}{l}\text { • Mężczyźni: } 126 \text { osób (28,0\%) } \\
\text { • Kobiety: } 324 \text { (72,0\%) }\end{array}$ \\
\hline Rok studiów & $\begin{array}{l}\text { - Pierwszy: } 214 \text { osób (46,8\%) } \\
\text { - Ostatni: } 243 \text { osoby (53,2\%) }\end{array}$ \\
\hline Kierunek studiów & $\begin{array}{l}\text { - Pedagogika: } 145(31,8 \%) \\
\text { - Prawo: } 158(34,7 \%) \\
\text { - Medycyna: } 121(26,5 \%) \\
\text { - Teologia: } 32(7,0 \%)\end{array}$ \\
\hline Miejsce pochodzenia & $\begin{array}{l}\text { - Miejscowość do } 9 \text { tys. mieszkańców: } 64 \text { osób (13,3\%) } \\
\text { - Miejscowość od } 10 \text { do } 99 \text { tys. mieszkańców: } 127 \text { osób (26,4\%) } \\
\text { - Miejscowość powyżej } 100 \text { tys. mieszkańców: } 290 \text { osób (60,3\%) }\end{array}$ \\
\hline Uczelnia & $\begin{array}{l}\text { - UwB: } 305 \text { osób }(66,7 \%) \\
\text { - UMwB: } 119 \text { osób }(26,1 \%) \\
\text { - AWSDwB: } 18 \text { osób }(3,9 \%) \\
\text { - WSDimP: } 15 \text { osób }(3,3 \%)\end{array}$ \\
\hline
\end{tabular}

Źródło: opracowanie własne.

stoku, Archidiecezjalnego Wyższego Seminarium Duchownego w Białymstoku oraz Wyższego Seminarium Duchownego im. Jana Pawła II w Łomży.

Zebrany materiał empiryczny opracowałam statystycznie przez zastosowanie: miar tendencji centralnej (średnia arytmetyczna (x), mediana (Me), kwartyl pierwszy (Q1), kwartyl trzeci (Q3), dominanta (D)); miary rozproszenia (odchylenie standardowe (SD), rozstęp, współczynnik zmienności (V)); miary badające kształt rozkładu (kurtoza (K), skośność (A), nieparametryczne testy statystyczne).

\section{WYNIKI BADAŃ}

\subsection{POSTAWY BADANYCH WOBEC TRANSPLANTACJI}

Trójkomponentowa definicja postawy i spójne z nią założenia metodologiczne zrealizowanych badań umożliwiły opracowanie empirycznego modelu analizowanego pojęcia. Model postawy studentów wobec transplantacji schematycznie przedstawia się następująco: Postawa wobec transplantacji = komponent poznawczy (Wiedzy) + komponent uczuciowo-motywacyjny (Uczucia) + komponent behawioralny (Zachowania). 
Opracowanie modelu empirycznego postaw wobec transplantacji umożliwiło zdiagnozowanie wpływu poszczególnych komponentów tworzących postawę na jej ostateczny kształt. Pozwoliło to na charakterystykę postaw (opartą na trzech poziomach/rodzajach) wobec transplantacji jako tych reprezentujących:

- poziom niski - postawy nieprzychylne transplantacji, czyli antytransplantacyjne;

- poziom średni - postawy ambiwalentne wobec transplantacji;

- poziom wysoki - postawy przychylne transplantacji, czyli protransplantacyjne.

Tabela 1. Postawy badanych studentów wobec transplantacji. Statystyki opisowe $(\mathrm{N}=457)$

\begin{tabular}{ccccccccccc}
\hline Wymiar & $\mathbf{N}$ & $\mathbf{M}$ & $\mathbf{s d}$ & $\mathbf{V ( x )}$ & $\mathbf{M e}$ & $\mathbf{D}$ & $\mathbf{m i n}$ & $\mathbf{m a x}$ & $\mathbf{A}$ & $\mathbf{K}$ \\
\hline Ogółem & 457 & 51,17 & 9,45 & $18,0 \%$ & 53 & 53 & 2 & 72 & $-2,56$ & 9,47 \\
\hline
\end{tabular}

sd - odchylenie standardowe; dom - dominanta, Me -mediana, M - średnia arytmetyczna, D - dominanta, A - skośność, K - kurtoza, V(x) - współczynnik zmienności

Źródło: opracowanie własne.

Najwięcej studentów (95\%) posiada średni poziom postawy wobec transplantacji (postawy ambiwalentne). Protransplantacyjną postawę ma zaledwie $1 \%$ badanych. $4 \%$ osób wykazuje postawy antytransplantacyjne. Ten wynik wydaje się dalece niesatysfakcjonujący, mając na względzie fakt, że badaniom podlegała grupa młodzieży akademickiej, w założeniu najzdolniejsza w swoim pokoleniu, która w przyszłości może decydować o kształcie społecznych nurtów intelektualnych. Opis statystyczny odnoszący się do postaw badanych zawiera tabela 1.

Tabela 2. Komponent Wiedza. Statystyki opisowe $(\mathrm{N}=459)$

\begin{tabular}{lcccccccccc}
\hline Wymiar & $\mathbf{N}$ & $\mathbf{M}$ & sd & $\mathbf{V}(\mathbf{x})$ & $\mathbf{M e}$ & $\mathbf{D}$ & $\mathbf{m i n}$ & $\mathbf{m a x}$ & $\mathbf{A}$ & $\mathbf{K}$ \\
\hline Ogółem & 459 & 5,54 & 1,79 & $32,3 \%$ & 6 & 5 & 0 & 10 & $-0,26$ & $-0,04$ \\
\hline
\end{tabular}

sd - odchylenie standardowe; dom - dominanta, Me - mediana, M - średnia arytmetyczna, D - dominanta, A - skośność, K - kurtoza, V(x) - współczynnik zmienności

Źródło: opracowanie własne.

Z analizy danych wynika, że 74,9\% respondentów posiada średni poziom wiedzy w zakresie transplantacji. Natomiast tylko 13,3\% badanych studentów posiada wysoki poziom wiedzy o transplantacjach. Podobny odsetek badanych studentów $(11,8 \%)$ odznacza się niskim poziomem wiedzy na ten temat. Uzyskane wyniki wydają się dalece niewystarczające, mając na względzie z jednej strony ważność metod transplantacji w utrzymaniu dobrostanu człowieka i potrzeb 
społecznych w tym zakresie, z drugiej zaś fakt, że badaniom podlegały osoby reprezentujące wysoki poziom wykształcenia w danym pokoleniu. Wydaje się, że naturalnym imperatywem pedagogicznym jest podnoszenie poziomu wiedzy młodzieży akademickiej, choćby przez promowanie idei transplantacji w toku zajęć dydaktycznych ze studentami.

Postawy studentów wobec transplantacji obok wiedzy, jaką dysponują młodzi ludzie, to także ich uczucia odnoszące się do tej metody leczenia. Prezentowane badania służyły określeniu rodzaju przejawianych w stosunku do tej metody leczenia uczuć, w rozróżnieniu na pozytywne, negatywne i ambiwalentne.

Tabela 3. Komponent Uczucia. Statystyki opisowe ( $\mathrm{N}=437)$

\begin{tabular}{ccccccccccc}
\hline Wymiar & $\mathbf{N}$ & $\mathbf{M}$ & $\mathbf{s d}$ & $\mathbf{V}(\mathbf{x})$ & $\mathbf{M e}$ & $\mathbf{D}$ & $\mathbf{m i n}$ & $\mathbf{m a x}$ & $\mathbf{A}$ & $\mathbf{K}$ \\
\hline Ogółem & 437 & 21,69 & 4,24 & $19,5 \%$ & 22 & 22 & 4 & 35 & $-0,17$ & 1,63 \\
\hline
\end{tabular}

sd - odchylenie standardowe; Me - mediana, M - średnia arytmetyczna, D - dominanta, A - skośność, $\mathrm{K}$ - kurtoza, $\mathrm{V}(\mathrm{x})$ - współczynnik zmienności

Źródło: opracowanie własne.

Z analizy uzyskanych danych wynika, że zdecydowana większość badanych osób (93,8\%) posiada ambiwalentny stosunek uczuciowo-motywacyjny wobec transplantacji. Uzyskane wyniki uznaję za zaskakujące, gdyż wśród młodzieży akademickiej tylko 1,2\% ma wyraźnie pozytywny stosunek wobec transplantacji. Jednocześnie 5\% respondentów charakteryzuje się stosunkiem negatywnym wobec metody leczenia będącej szansą na zachowanie zdrowia i życia ludzi, w przypadku których inne procedury medyczne nie gwarantują pozytywnych efektów. Uzyskane wyniki wskazują na wyraźną lukę w zakresie upowszechniania idei transplantacji w środowisku akademickim.

Medycyna transplantacyjna jest zależna od zachowań zarówno dawców narządów, jak i biorców, decydujących się na taką formę leczenia. Zamiary, pragnienia, plany oraz deklarowane działania i zachowania studentów w zakresie dawstwa narządów tworzą komponent behawioralny postawy wobec transplantacji. Wyniki badań uzyskane dla komponentu behawioralnego pokazują postawy studentów,

Tabela 4. Komponent Zachowania. Statystyki opisowe ( $\mathrm{N}=448)$

\begin{tabular}{ccccccccccc}
\hline Wymiar & $\mathbf{N}$ & $\mathbf{M}$ & sd & $\mathbf{V}(\mathbf{x})$ & $\mathbf{M e}$ & $\mathbf{D}$ & $\mathbf{m i n}$ & $\mathbf{m a x}$ & $\mathbf{A}$ & $\mathbf{K}$ \\
\hline Ogółem & 448 & 24,77 & 5,21 & $21,0 \%$ & 25 & 5 & 4 & 32 & $-0,68$ & 0,34 \\
\hline
\end{tabular}

sd - odchylenie standardowe; Me - mediana, M - średnia arytmetyczna, D - dominanta, A - skośność, $\mathrm{K}$ - kurtoza, V(x) - współczynnik zmienności

Źródło: opracowanie własne. 
który określiłam jako komponent Zachowania. Przyjęłam trzy poziomy nasilenia zachowań związanych z tematyką transplantacyjną.

Uzyskane wyniki są optymistyczne, gdyż 75,5\% badanych deklaruje protransplantacyjne zachowania. Deklaracji zachowań przeciwnych, czyli antytransplantacyjnych, w badanej grupie było zaledwie 1,3\%, a pośrednich, ambiwalentnych 23,2\%. Uzyskane wyniki wpisują się w ogólnoświatową tendencję wysokiej deklaratywności zachowań protransplantacyjnych (zob. np. Li i in., 2001; Gorzkowicz, 2010; Sanawi i in., 2009). Trzeba oczywiście wziąć pod uwagę, że są to jedynie deklaracje, więc, niestety, mogą być rzadko realizowane w rzeczywistości społecznej.

\subsection{POCZUCIE KOHERENCJI OSÓB BADANYCH}

W celu zmierzenia poziomu poczucia koherencji do wyznaczenia granic poszczególnych przedziałów przyjęłam metodę równiej rozpiętości trzech przedziałów. Do wyznaczenia rozpiętości przedziałów skorzystałam ze wzoru:

$$
h \approx \frac{x_{\max }-x_{\min }}{k} \approx \frac{R}{K}
$$

gdzie: $\mathrm{h}$ - rozpiętość klas; $\mathrm{k}$ - liczba przedziałów (wariantów cechy); $x_{\min }-$ najmniejsza wartość cechy; $x_{\max }$ - największa wartość cechy; $\mathrm{R}$ - rozstęp między najmniejszą i największą wartością cechy.

Z otrzymanych wyników badań dla poczucia koherencji oraz jej poszczególnych komponentów (zaradności, sensowności i zrozumiałości) zostały wyznaczone przedziały:

- poziom niski,

- poziom średni,

- poziom wysoki.

Wyniki badań poczucia koherencji i jego podskal oraz statystyki opisowe zaprezentowano w tabeli 5.

Tabela 5 Poczucie koherencji (SOC-29)

\begin{tabular}{lcccccccc}
\hline \multirow{2}{*}{ Poziom } & \multicolumn{2}{c}{ Koherencja } & \multicolumn{2}{c}{ Zaradność } & \multicolumn{2}{c}{ Sensowność } & \multicolumn{2}{c}{ Zrozumiałość } \\
\hline & Liczba & \% & Liczba & \%t & Liczba & \% & Liczba & \% \\
\hline Niski wynik & 38 & $9,6 \%$ & 24 & $6,0 \%$ & 21 & $5,3 \%$ & 139 & $35,0 \%$ \\
\hline Średni wynik & 292 & $73,6 \%$ & 279 & $70,3 \%$ & 202 & $50,9 \%$ & 245 & $61,7 \%$ \\
\hline
\end{tabular}




\begin{tabular}{|c|c|c|c|c|c|c|c|c|}
\hline \multirow[t]{2}{*}{ Poziom } & \multicolumn{2}{|c|}{ Koherencja } & \multicolumn{2}{|c|}{ Zaradność } & \multicolumn{2}{|c|}{ Sensowność } & \multicolumn{2}{|c|}{ Zrozumiałość } \\
\hline & Liczba & $\%$ & Liczba & $\% t$ & Liczba & $\%$ & Liczba & $\%$ \\
\hline Wysoki wynik & 67 & $16,9 \%$ & 94 & $23,7 \%$ & 174 & $43,8 \%$ & 13 & $3,3 \%$ \\
\hline n ważnych & 397 & $100 \%$ & 397 & $100 \%$ & 397 & $100 \%$ & 397 & $100 \%$ \\
\hline Średnia & 127,4 & 45,1 & 39,8 & 42,5 & & & & \\
\hline $\begin{array}{l}\text { Odchylenie } \\
\text { standardowe }\end{array}$ & 21,9 & 8,7 & 8,2 & 8,0 & & & & \\
\hline Minimum & 54 & 13 & 13 & 22 & & & & \\
\hline Maksimum & 196 & 70 & 56 & 76 & & & & \\
\hline Mediana & 125 & 45 & 40 & 42 & & & & \\
\hline
\end{tabular}

Źródło: opracowanie własne.

Uzyskane wyniki badań wskazują, że większość badanej grupy, 73,6\%, charakteryzuje się średnim poziomem poczuciem koherencji. W zakresie podskal zastanawiają wysokie wyniki uzyskane w skali sensowności (łącznie ponad 94\% wyników średnich i wysokich, a nieco ponad 5\% wyników niskich) przy dużo niższym wyniku poziomu zrozumiałości (łącznie wyniki średnie i wysokie 65\%, oraz 35\% wyników niskich). Dominuje średni wynik osiągany w skali zaradności (nieco ponad 70\% wyników średnich, ponad 23\% wyników wysokich i 6\% wyników niskich).

Za zasadne uznałam zweryfikowanie na drodze empirycznej, czy postawy studentów wobec metody terapeutycznej, jaką jest transplantacja, są warunkowane poczuciem koherencji, jakim charakteryzują się badani. Graficznie i opisowo przedstawiam charakterystyki ukazujące zależności pomiędzy postawą wobec transplantacji z uwzględnieniem jej trzech komponentów a poczuciem koherencji badanych, które także jest konstruktem trójkomponentowym. Szczegółowe wyniki analiz statystycznych przedstawiono w tabeli 6 i na wykresie 1.

Tabela 6. Współczynniki korelacji oraz wartość p dla poczucia koherencji (SOC-29) i szczegółowych komponentów postawy wobec transplantacji (PWT)

\begin{tabular}{lcc}
\hline Zależność & $\mathbf{r}$ & $\mathbf{p}$ \\
\hline SOC-29 a wiedza & $\mathbf{0 , 1 7}$ & $\mathbf{0 , 0 0 0 8}$ \\
\hline SOC-29 a zachowanie & 0,03 & 0,6224 \\
\hline SOC-29 a emocje & $-0,09$ & 0,1032 \\
\hline SOC-29 a PWT & 0,04 & 0,4834 \\
\hline
\end{tabular}

Źródło: opracowanie własne. 


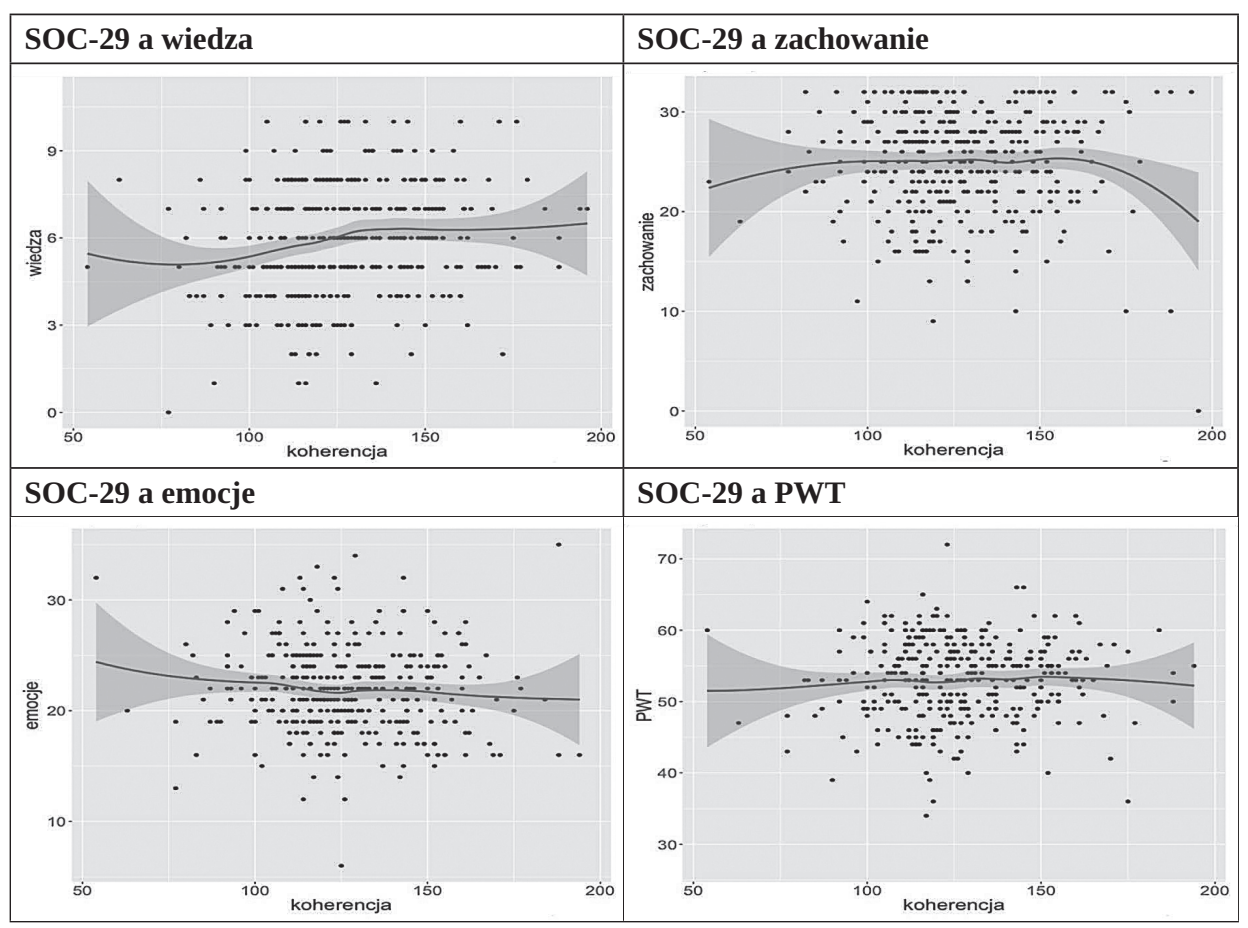

Wykres 1. Zależność poczucia koherencji (SOC-29) oraz poszczególnych komponentów postawy wobec transplantacji

Źródło: opracowanie własne.

Przeprowadzone analizy statystyczne wykazały, że nie istnieje zależność, która uprawniałaby do stwierdzenia, że poczucie koherencji (SOC-29) badanych ma istotny statystycznie związek z ich postawą wobec transplantacji. Na poziomie ogólnych porównań tych zmiennych nie można dostrzec ich wzajemnej korelacji. Jednakże, kiedy przejdziemy z optyki ogólnej na poziom analiz szczegółowych, czyli tworzących zarówno postawę wobec transplantacji, jak i komponentów poczucia koherencji, wyniki uzyskanych badań są niezwykle interesujące. Poczucie koherencji (SOC-29) koreluje dodatnio z jednym z komponentów tworzących postawę wobec transplantacji. Chodzi o poziom Wiedzy ( $\mathrm{p}=0,0008)$, co oznacza, iż osoby z wysokim poczuciem koherencji istotnie częściej posiadają wyższy poziom Wiedzy odnoszącej się do transplantacji. Wyniki badań potwierdziły istnienie zależności pomiędzy poziomem Wiedzy badanych związanej z zagadnieniem transplantacji a wszystkimi komponentami tworzącymi poczucie koherencji, tj. poczucie zaradności, poczucie sensowności i poczucie zrozumiałości. 
Poczucie zaradności koreluje dodatnio z poziomem Wiedzy ( $\mathrm{p}=0,0010)$, co oznacza, że osoby z wysokim poczuciem zaradności istotnie częściej posiadają wyższy poziom wiedzy odnoszącej się do tematyki transplantacyjnej. Wyniki prezentuję w tabeli 7 na wykresie 2 .

Tabela 7. Współczynniki korelacji oraz wartość p dla poczucia zaradności i poszczególnych komponentów postawy wobec transplantacji

\begin{tabular}{lcc}
\hline Zależność & $\mathbf{r}$ & $\mathbf{p}$ \\
\hline Zaradność a wiedza & $\mathbf{0 , 1 6}$ & $\mathbf{0 , 0 0 1 0}$ \\
\hline Zaradność a zachowanie & 0,07 & 0,1780 \\
\hline Zaradność a emocje & $-0,08$ & 0,1315 \\
\hline Zaradność a PWT & 0,07 & 0,1711 \\
\hline
\end{tabular}

Źródło: opracowanie własne.

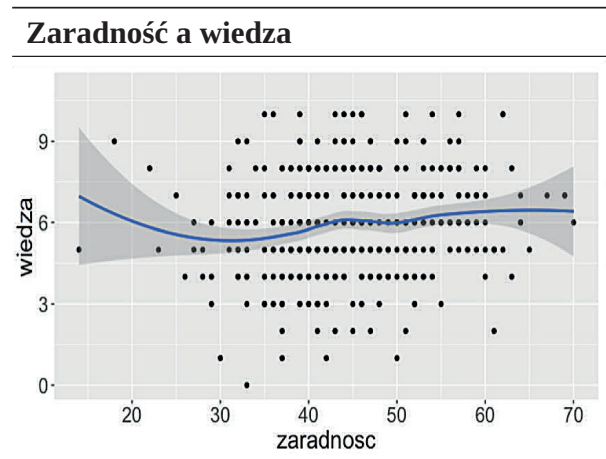

Zaradność a zachowanie
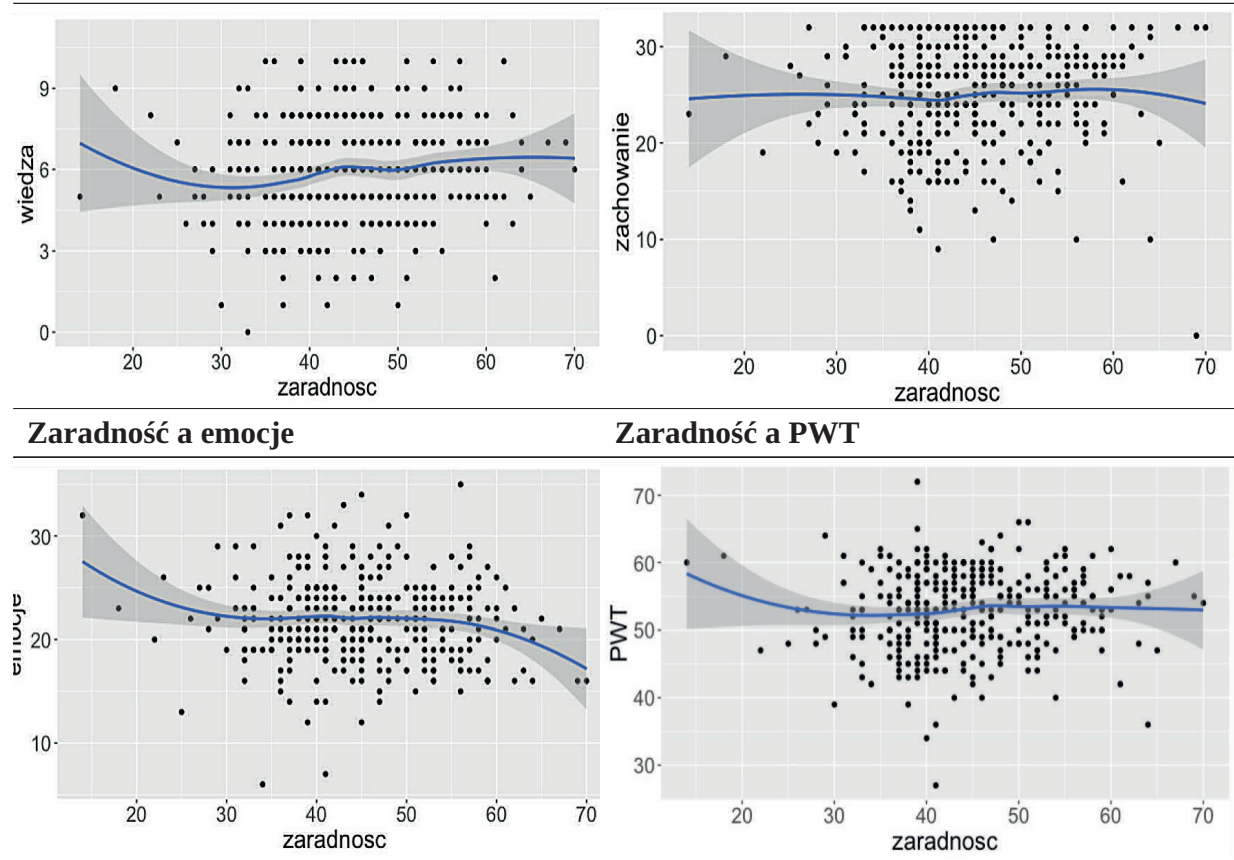

Zaradność a PWT

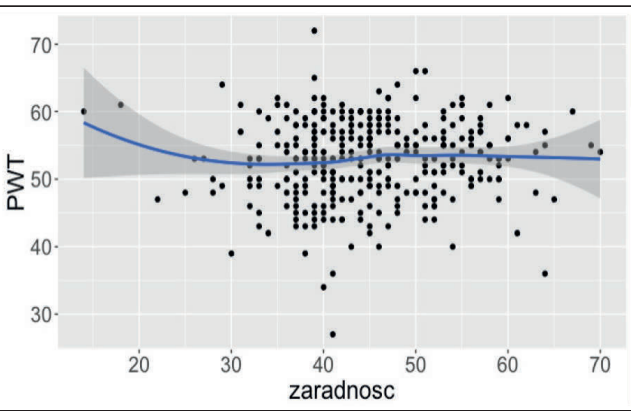

Wykres 2 Zależność pomiędzy poczuciem zaradności a poszczególnymi komponentami postawy wobec transplantacji

Źródło: opracowanie własne. 
Zaradność jako predyspozycja osobowa w świetle prezentowanych wyników determinuje chęć poszerzania wiedzy, również w zakresie informacji o idei transplantacji.

Poczucie sensowności koreluje dodatnio z poziomem Wiedzy ( $\mathrm{p}=0,0006)$, co oznacza, że osoby z wysokim poczuciem sensowności istotnie częściej posiadają wyższy poziom wiedzy odnoszącej się do tematyki transplantacyjnej. Wyniki przedstawiono w tabeli 8 i na wykresie 3.

Tabela 8. Współczynniki korelacji oraz wartość p dla poczucia sensowności a poszczególnymi komponentami postawy wobec transplantacji

\begin{tabular}{lcc}
\hline Zależność & $\mathbf{r}$ & $\mathbf{p}$ \\
\hline Sensowność a wiedza & $\mathbf{0 , 1 7}$ & $\mathbf{0 , 0 0 0 6}$ \\
\hline Sensowność a zachowanie & 0,03 & 0,6084 \\
\hline Sensowność a emocje & $-0,05$ & 0,3565 \\
\hline Sensowność a PWT & 0,07 & 0,1813 \\
\hline
\end{tabular}

Źródło: opracowanie własne.
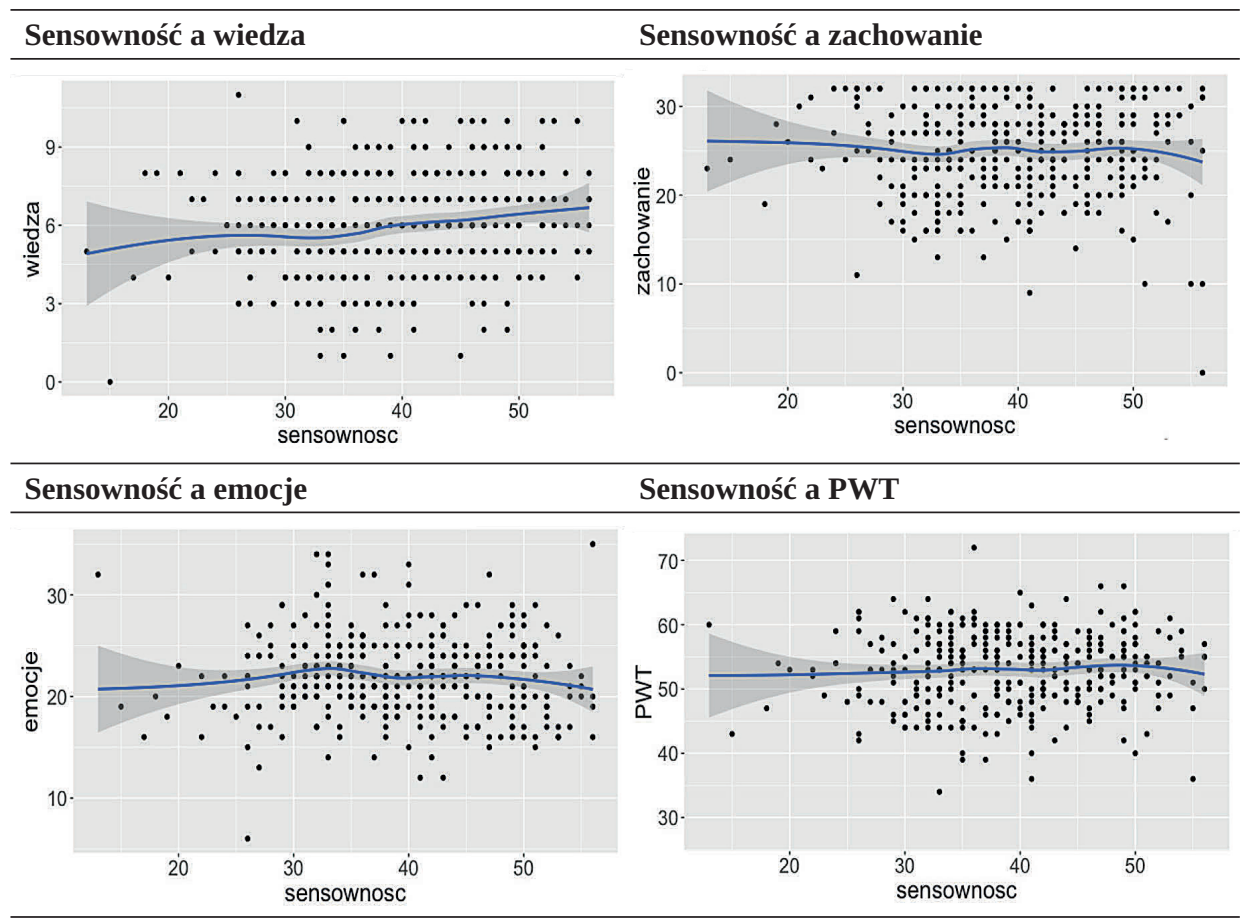

Wykres 3. Zależność pomiędzy poczuciem sensowności a poszczególnymi komponentami postawy wobec transplantacji

Źródło: opracowanie własne. 
Kolejny komponent poczucia koherencji, czyli sensowność, w świetle prezentowanych wyników również stymuluje chęć poszerzania wiedzy o transplantacji.

Poczucie zrozumiałości koreluje dodatnio z poziomem Wiedzy ( $\mathrm{p}=0,0010)$, co oznacza, że osoby z wysokim poczuciem zrozumiałości istotnie częściej posiadają wyższy poziom wiedzy odnoszącej się do tematyki transplantacyjnej. Wyniki zaprezentowano w tabeli 9 i na wykresie 4.

Tabela 9. Współczynniki korelacji oraz wartość p dla poczucia zrozumiałości i poszczególnych komponentów postawy wobec transplantacji

\begin{tabular}{lcc}
\hline Zależność & $\mathbf{r}$ & $\mathbf{p}$ \\
\hline Zrozumiałość a wiedza & $\mathbf{0 , 1 2}$ & $\mathbf{0 , 0 1 8 2}$ \\
\hline Zrozumiałość a zachowanie & 0,03 & 0,5344 \\
\hline Zrozumiałość a emocje & $-0,11$ & 0,0287 \\
\hline Zrozumiałość a PWT & 0,01 & 0,9840 \\
\hline
\end{tabular}

Źródło: opracowanie własne.

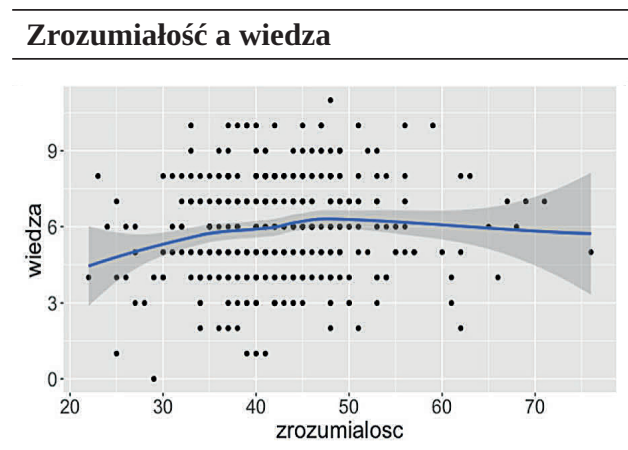

Zrozumiałość a zachowanie

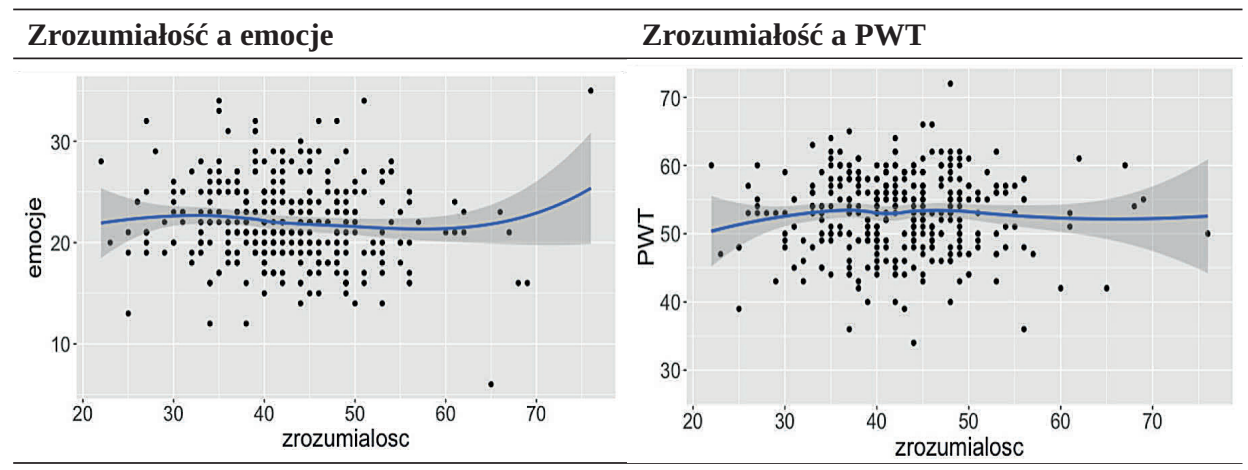

Wykres 4. Zależność poczucia zrozumiałości oraz poszczególnych parametrów Postawy Wobec Transplantologii

Źródło: opracowanie własne. 
Zrozumiałość w świetle prezentowanych wyników dodatnio koreluje z poziomem wiedzy na temat transplantacji, ponieważ w dużej części budowana jest sferą poznawczą człowieka.

\section{DYSKUSJA WYNIKÓW}

Zaprezentowane wyniki badań ukazują dość niepokojący obraz postawy młodzieży akademickiej wobec transplantacji oraz jej zależności od poziomu koherencji badanych studentów. Większość (95\%) badanych posiada ambiwalentne postawy wobec transplantacji. Zaskakuje fakt, że zaledwie w przypadku 1\% ogółu badanych ich postawę można scharakteryzować jako protransplantacyjną, przy czym 4\% spośród osób respondentów wykazuje postawy antytransplantacyjne. Ten wynik, zwłaszcza z perspektywy pedagogiki społecznej, wydaje się dalece niesatysfakcjonujący. Jak zauważa Syrek, to właśnie pedagogika społeczna „eksponuje relacje między jednostką a środowiskiem i wskazuje na ich konsekwencje prakseologiczne, co umożliwia ich przenikanie między różnymi dziedzinami, jak np. praca, wypoczynek, zdrowie, edukacja” (Syrek, 2009, s. 18). Tak niewielka liczba osób przejawiająca obecnie postawę protransplantacyjną stanowi wyzwanie dla edukacji i pedagogiki. Niedosyt potęguje fakt, że badaniom podlegała grupa młodzieży akademickiej, która w przyszłości może decydować o kształcie społecznych nurtów intelektualnych. W wielu badaniach podkreśla się, że dużą rolę w procesie opiniotwórczym odgrywać mogą studenci, ponieważ przejawiają oni wysoki poziom zaangażowania społecznego (Nowak, 2014), a studia z założenia są procesem, który kształtuje i warunkuje ostateczny kształt postawy wobec różnych zjawisk społecznych. Wiedza jest kluczowym komponentem w strukturze postawy badanych w zakresie transplantacji. Z dokonanej analizy wyników badań wnioskuję, że badani posiadają przeciętny (średni) poziom wiedzy o transplantacjach. Taki wynik potwierdza, jak ważne jest nie tylko dostarczanie wiedzy, podanie jej w atrakcyjnej formie, ale też rozbudzanie ciekawości poznawczej młodego pokolenia dotyczącej ważnych problemów społecznych. Drugim badanym elementem budującym ogólny wskaźnik postawy wobec transplantacji był komponent uczuciowo-motywacyjny. Dominuje w wynikach postawa ambiwalentna badanych wobec zjawiska transplantacji. Zaskakujące są również proporcje pozytywnego stosunku wobec transplantacji, zaledwie $1 \%$ badanych, przy $5 \%$ udziale badanych studentów, którzy mają wyraźnie negatywny stosunek. To skłania do refleksji, że oprócz zilustrowanych wcześniej deficytów w zakresie wiedzy, niejednoznaczny jest też stosunek emocjonalny badanej młodzieży wobec transplantacji. Na pod- 
stawie uzyskanych wyników stwierdzam, że badani deklaratywnie przejawiają zachowania protransplantacyjne, co wynika z wysokiego poziomu potencjalnie prezentowanych zachowań. W świetle wyników osiąganych przez respondentów w zakresie dwóch poprzednich komponentów postawy komponent behawioralny wydaje się najbardziej budujący.

Bardziej optymistycznie kształtują się wyniki w zakresie osiąganego ogólnego wskaźnika poczucia koherencji badanej młodzieży akademickiej. Większość badanej grupy charakteryzuje się średnim poziomem poczucia koherencji. W zakresie podskal zastanawiają wysokie wyniki uzyskane w skali sensowności przy dużo niższym wyniku poziomu zrozumiałości. Całości dopełnia dominacja średniego wyniku osiąganego w skali zaradności. Może to stanowić zalążek tezy, że poziom wykształcenia pozytywnie oddziałuje na kształtowanie się poczucia koherencji młodego pokolenia, na poziomie poczucia sensowności, zrozumiałości oraz zaradności.

Pomimo braku istotnej statystycznie zależności pomiędzy ogólnym wskaźnikiem poczucia koherencji badanej młodzieży a ich postawą wobec transplantacji już na poziomie analiz zależności wśród poszczególnych podskal obu zmiennych widać pewne interesujące zależności i tendencje. Zwłaszcza dla mnie, jako pedagoga postulującego wzbogacenie propagowania idei przeszczepów o edukacji zdrowotnej w tym obszarze, czyli przekazywania wiedzy z zakresu transplantologii, interesujący wydaje się fakt, że poczucie koherencji koreluje dodatnio z jednym z komponentów tworzących postawę wobec transplantacji (wiedza). Oznacza to, że osoby z wysokim poczuciem koherencji istotnie częściej posiadają wyższy poziom wiedzy odnoszącej się do transplantacji. Wyniki badań potwierdziły istnienie zależności pomiędzy poziomem wiedzy badanych związanej z zagadnieniem transplantacji a wszystkimi komponentami tworzącymi poczucie koherencji, tj. poczucie zaradności, poczucie sensowności i poczucie zrozumiałości. Predyspozycja osobowa, jaką jest zaradność, w świetle prezentowanych wyników, determinuje chęć poszerzania wiedzy, również w zakresie informacji o idei transplantacji. Zakłada bowiem przygotowanie się osoby do różnych ewentualności, również dotyczących potencjalnych własnych problemów zdrowotnych oraz osób bliskich. Sensowność jako kolejny komponent poczucia koherencji, w świetle prezentowanych wyników, również stymuluje chęć poszerzania wiedzy o transplantacji. Zastanawia natomiast brak korelacji tego komponentu z pozostałymi elementami postawy, co w przypadku poczucia sensowności wydawałoby się naturalną konsekwencją. Zrozumiałość również dodatnio koreluje z poziomem wiedzy na temat transplantacji. W tym przypadku jest to związane z naturalną zależnością wypełniania przestrzeni zrozumiałości dużą ilością szerokiej w swoim 
zakresie wiedzy na temat wszelkich prawidłowości i nieprawidłowości świata i uruchamiania przede wszystkim sfery poznawczej.

\section{ZAKOŃCZENIE}

Zaprezentowane wyniki ukazują wyraźną lukę w zakresie kształtowania odpowiednich postaw wobec transplantacji w warstwie dobrych praktyk i przykładów konkretnych zachowań, które mogłyby stanowić inspiracje dla młodego pokolenia. Przede wszystkim uzyskane wyniki wskazują na konieczność wdrożenia edukacji zdrowotnej z zakresu tematyki transplantacyjnej, która powinna polegać na przekazywaniu wiedzy naukowej odnoszącej się do poruszanego zagadnienia, jednakże, co istotne, powinna być prowadzona w dyskursie interdyscyplinarnym. Prowadzone w taki sposób dyskusje pozwolą na skuteczne kształtowanie świadomości społecznej w tym zakresie. Badania pokazują, że programy edukacyjne adresowane specjalnie do studentów w zakresie dawstwa narządów mają pozytywny wpływ na wzrost liczby dawców narządów wśród tej grupy społecznej (Hassan, Batool, 2015).

Tadeusz Lewowicki zauważa, że: „przy wszelkich różnicach w pojmowaniu i uprawianiu pedagogiki, społeczną racją istnienia tej dyscypliny nie przestaje być jej przydatność praktyczna, pozytywne oddziaływanie na życie społeczne” (Lewowicki, 2007, s. 114). Uważam, że wyzwaniem stającym przed pedagogiką jest podjęcie realizacji tak ważnego z perspektywy społecznej zadania, jakim jest wdrażanie edukacji zdrowotnej społeczeństwa, mającej na celu kształtowanie postaw społecznych wobec transplantacji. Myślę, że włączenie się pedagogiki w dyskusję społeczną dotyczącą transplantacji przez edukację zdrowotną będzie niezwykle pożyteczne. Pozwoli sprowadzić dyskurs o transplantacji na poziom dyskusji społecznej, prowadzonej w ośrodkach akademickich, z których młodzież przeniesie ją do swoich rodzin, co w konsekwencji ma szansę stać się podstawą do kreowania postaw społecznych przychylnych tej metodzie leczenia.

\section{Bibliografia}

Antonovsky, A. (2005). Rozwikłanie tajemnicy zdrowia. Jak radzić sobie ze stresem i nie zachorować. Warszawa: Instytut Psychiatrii i Neurologii.

Antonovsky, A. (1987). Unraveling the mystery of health: How people manage stress and stay well. San Francisco: Jossey-Bass.

Binnebesel, J. (2006). Pedagogiczne możliwości kształtowania poczucia koherencji w kontekście salutogenetycznej koncepcji zdrowia A. Antonovsky'ego. Psychoonkologia, 10 (2), s. 64-69. 
Cudowska, A. (2017). Twórcze orientacje życiowe. Zdrowie i dobrostan. Białystok: Wydawnictwo Uniwersytetu w Białymstoku.

Dolińska-Zygmunt, G. (2001). Orientacja salutogenetyczna w problematyce zdrowotnej. Model Antonovsky'ego. W: G. Dolińska-Zygmunt (red.), Podstawy psychologii zdrowia (s. 19-31). Wrocław: Wydawnictwo Uniwersytetu Wrocławskiego.

Gorzkowicz, B. i in. (2010). Opinia na temat dawstwa narządów wśród studentów uczelni wyższych Szczecina. Problemy pielęgniarstwa, 18 (2).

Guzik-Makaruk, E.M. (2008). Transplantacja organów, tkanek i komórek w ujęciu prawnym i kryminologicznym. Białystok: Temida 2.

Hassan, E., Batool, T. (2015). Nursing students' attitudes towards brain death and organ transplantation in southeast Iran. Transplant Journal of Australasia, 2 (24), s. 20-25.

Kaiser G. (1966). Kunsliche Insemination und Transplantation. W: H. Göppinger (red.), Arzt und Recht: Medizinisch-juristische Grenzprobleme unserer Zeit. München.

Katz, D., Stotland, E. (1959). A Preliminary Statement to a Theory of Attitude Structure and Change. W: S. Koch (red.), Psychology, a Study of Science, t. 3. New York: McGraw-Hill.

Komunikat z Badań CBOS (2016). Postawy wobec przeszczepiania narzq̨dów, nr 119 /20016, Warszawa.

Lewowicki, T. (2007). O tożsamości, kondycji i powinnościach pedagogiki. Radom: Instytut Technologii Eksploatacji - Państwowy Instytut Badawczy.

Li, P.K. i in. (2001). Attitudes about organ and tissue donation among the general public and blood donors in Hong Kong. Pobrane z: http://www.ncbi.nlm.nih.gov/ pubmed/11871053.

Lina-Ćwikła, A. (2018). Pedagogiczne Uwarunkowania Poczucia Koherencji. Roczniki Pedagogiczne, t. 10(46), nr 3. DOI: Http://Dx.Doi.Org/10.18290/Rped.2018.10.3-3.

Mattila, M.L. i in. (2011). Sense of coherence and health behaviour in adolescence. Acta Paediatrica, 100(12), s. 1590-1595.

Mittelmark, M.B. i in. (2017). The Handbook of Salutogenesis. Cham: Springer.

Mroziak, B. (1996). Poczucie koherencji (SOC) a zdrowie psychiczne i picie alkoholu przez młodzież. Alkoholizm i Narkomania, 1, 27-35.

Perkowska, M.M. (2019). Postawy młodzieży akademickiej wobec transplantacji. Białystok: Temida 2.

Sęk, H. (2001). Salutogeneza i funkcjonalne właściwości poczucia koherencji. W: H. Sęk, T. Pasikowski (red.), Zdrowie - stres - zasoby. O znaczeniu poczucia koherencji dla zdrowia (s. 23-42.) Poznań: Wydawnictwo Fundacji Humaniora.

Smith, M.B. (1967). The Personal Setting of Public Opinions. W: M. Fishbein (red.), Readings in Attitude Theory and Measurement. New York: John Wiley \& Sons Inc.

Syrek, E. (2008). Zdrowie i wychowanie a jakość życia. Perspektywy i humanistyczne orientacje poznawcze. Katowice: Wydawnictwo Uniwersytetu Śląskiego.

Syrek, E., Borzucka-Sitkiewicz, K. (2009). Edukacja zdrowotna. Warszawa: Wydawnictwa Akademickie i Profesjonalne.

Woynarowska, B. (2007). Edukacja zdrowotna. Podręcznik akademicki. Warszawa: Wydawnictwo Naukowe PWN. 